\title{
Antioxidant activity and hepatoprotective effect of Cichorium intybus (Kasni) seed extract against carbon tetrachloride-induced liver toxicity in rats
}

\author{
Amna Khalid", Sammia Shahid", Shakeel Ahmad Khan ${ }^{1 \star}$, Sadia Kanwal ${ }^{2}$, Atif \\ Yaqoob $^{3}$, Zahid Ghulam Rasool ${ }^{1}$, Komal Rizwan ${ }^{4}$ \\ ${ }^{1}$ Department of Chemistry, School of Science, University of Management and Technology, ${ }^{2}$ Department of Biochemistry, \\ University of Agriculture, Faisalabad-38000, ${ }^{3}$ Department of Zoology, Government College University, Lahore-54000, Pakistan, \\ ${ }^{4}$ Department of Chemistry, Government College Women University, Faisalabad, Pakistan
}

*For correspondence: Email: Shakilahmad56@gmail.com; Tel: +82-0106638912

Sent for review: 8 March 2018

Revised accepted: 25 July 2018

\begin{abstract}
Purpose: To assess the antioxidant and hepatoprotective activity of the aqueous-methanol extract of Cichorium intybus seeds (C. intybus) against carbon tetrachloride (CCl 4$)$-induced liver toxicity in albino Wistar rats.

Method: The seed extract of C. intybus was prepared in aqueous methanol (20:80) via Soxhlet solvent extraction process. $\mathrm{CCl}_{4}(0.8 \mathrm{~mL} / \mathrm{kg})$ was administered to induce hepatic damage in Wistar rats. The seed extract (100, 250 and $500 \mathrm{mg} / \mathrm{kg}$ doses) and a $25 \mathrm{mg} / \mathrm{kg}$ dose of silymarin (as standard drug) were administered orally to separate groups of albino Wistar rats for 14 days. Blood samples from the rats were analyzed for biochemical markers for hepatic injury. The tissue samples of the rats were subjected to histopathological studies as well as analyzed for liver antioxidants.

Results: The results for biochemical markers revealed that the rats treated with the extract $(500 \mathrm{mg} / \mathrm{kg}$ dose) showed a maximum elevation of catalase (48.90 $\mu$ mole of $\mathrm{H}_{2} \mathrm{O}_{2}$ consumed $/ \mathrm{min} / \mathrm{mg}$ protein), glutothione peroxidase (22.1 mg GSH consumed/min/mg protein), superoxide dismutase (14.2 units $/ \mathrm{min} / \mathrm{mg}$ protein), and a reduction in glutathione (18.1 $\mu$ mole of $\mathrm{GSH} / \mathrm{mg}$ protein). Serum biochemical parameters including serum glutamate oxaloacetate transaminase (SGOT), serum glutamate pyruvate transaminase (SGPT), alkaline phosphate (ALKP), and direct bilirubin were significantly $(p<0.01)$ increased in the treated groups. Oral administration of different doses of $C$. intybus seed extract significantly $(p<0.01)$ protected the hepatic cells from impairment. The biochemical markers and hematological parameters were also normal in extract-treated rats in contrast to the standard (silymarin) and control groups.

Conclusion: The results show that $C$. intybus plant is potential a good natural source of natural hepatoprotective and antioxidants agents.
\end{abstract}

Keywords: Cichorium intybus, Antioxidant, Hepatoprotective Biomarkers, Silymarin, Hematological parameters

This is an Open Access article that uses a funding model which does not charge readers or their institutions for access and distributed under the terms of the Creative Commons Attribution License (http://creativecommons.org/licenses/by/4.0) and the Budapest Open Access Initiative (http://www.budapestopenaccessinitiative.org/read), which permit unrestricted use, distribution, and reproduction in any medium, provided the original work is properly credited.

Tropical Journal of Pharmaceutical Research is indexed by Science Citation Index (SciSearch), Scopus, International Pharmaceutical Abstract, Chemical Abstracts, Embase, Index Copernicus, EBSCO, African Index Medicus, JournalSeek, Journal Citation Reports/Science Edition, Directory of Open Access Journals (DOAJ), African Journal Online, Bioline International, Open-J-Gate and Pharmacy Abstracts 


\section{INTRODUCTION}

Liver disorders (jaundice, fatty liver, cirrhosis) are commonly affecting human health worldwide. Approximately $70-75 \%$ of the world's population depends on herbal medicines for curing diseases because they are cost- effective, less toxic, and easily available [1]. Major metabolic activities of body are taking place in liver [2]. Hepatic disorders usually develop during the process of removal of toxic and harmful chemicals from the liver [3]. Plants and their various parts (stem, roots, leaves, flowers, and fruits) are well known for the treatment of hepatic disorders $[4,5]$.

Approximately only $1-2 \%$ of plant species have been explored properly [6]. C. intybus (Family: Asteraceae) is a small perennial herb that is usually bushy in nature; its common name is chicory [7]. The colors of the flowers of $C$. intybus are usually blue, light purple, or lavender, but white or pink flowers have also been reported but very rarely [8].This plant is usually found as a wild plant grown along roadsides in Europe. $C$. intybus has different names when grown for its leaves such as leaf chicory, endive, or French endive [7]. Chicory has been used in conventional medicines throughout the world for hundreds of years [8]. In Iran, the parts of $C$. intybus other than the roots are mostly used to purify blood [9]. Extracts of seeds of chicory have also been used in Ayurvedic medicines for the treatment of hepatic disorders $[9,10]$.

C. intybus is also enlisted as a domestic plant usually grown for food, animal fodder, and to make traditional medicines [11]. Several reports are available on the chemical composition of $C$. intybus seeds, but little attention has been given to their hepatoprotective effects [11]. Therefore, we designed this research to evaluate the hepatoprotective and antioxidant potential of $C$. intybus seeds against $\mathrm{CCl}_{4}$ (carbon tetrachloride)-induced hepatic damage in rats.

\section{EXPERIMENTAL}

\section{Chemicals}

Chemicals and reagents such as butylated hydroxytoluene (BHT; $99.07 \%$ pure); 2, 2diphenyl-1-picrylhydrazyl (DPPH, $90.0 \%$ pure), linoleic acid, carbon tetrachloride $\left(\mathrm{CCl}_{4}\right)$, standard antibiotic drug (silymarin), standard kits for the determination of levels of serum enzymes such as serum glutamate oxaloacetate transaminase (SGOT), serum glutamate pyruvate (SGPT), alkaline phosphate (ALKP), and direct bilirubin (D. Bil) were purchased from Atlas Chemicals Co. (United Kingdom). Other reagents like normal saline, formalin, olive oil, and alcohol were of high quality and purchased from Sigma brands.

\section{Collection of plant material}

The seeds of $C$. intybus were collected from Lahore (Punjab, Pakistan) in March 2017. Prof Sohail Sheikh, Department of Botany, Govt. M.A.O College, Lahore, Pakistan, identified the plant seeds. A voucher specimen (no. GCHERB-570) was submitted to the herbarium of Govt. M.A.O College, Lahore, Pakistan for future reference.

\section{Sample and extract preparation}

First, plant seeds were washed to remove dust; after that, they were shade dried at a temperature of $25-30{ }^{\circ} \mathrm{C}$ [12]. With the help of a commercial blender (FTA-788, West point, Germany), seeds were pulverized and then sieved (150 mesh sieve $(0.065 \mathrm{~mm}))$ [13]. The resultant seed powder material was stored in an airtight container. The powder of plant seeds was placed in a Soxhlet extractor for hot extraction using water and methanol in the proportion of 20:80 as a solvent respectively [14]. The Soxhlet extraction process was performed continuously at a temperature of $70-75{ }^{\circ} \mathrm{C}$ for $6 \mathrm{hr}$. An aqueous-methanol seed extract was concentrated by the removal of excess quantity of solvent (water and methanol) using a rotary evaporator. The crude extract was refrigerated in an airtight bottle in a refrigerator for future use [15].

\section{Animals}

Wistar albino rats (male) weighing 150-180 g were used in experimental work. They were acquired from the Department of Zoology, GC University Lahore, Pakistan. The rats were housed for seven days before pharmacological experiments in the chemistry lab of the University of Management and Technology Lahore. The Wistar rats were kept in a $12 \mathrm{~h}$ light/dark cycle under appropriate climatic conditions. These conditions include ac temperature of $23 \pm 2{ }^{\circ} \mathrm{C}$ and humidity of $40-45 \%$. All the animals were grouped into five groups and each group consisted of six rats. Each group was provided a standard normal diet and water. Before the start of the experiment, all the animals were adapted to their surroundings for almost 7 days. For the animal experiments, approval (reg no. KMCRET/MS/03/2017) was obtained from the Institutes of Animal Ethics Committee (IAEC) and the studies followed international guidelines [16]. 


\section{Determination of acute oral toxicity}

By following the guideline of OECD for the testing of chemicals, (Test No. 423 (OECD); acute oral toxicity-acute toxic class method), an acute oral toxicity study was carried out. Five rats $(n=5)$ were used for this study [17]. The animals were kept under observation continuously for 24 $\mathrm{h}$ and allowed access to water, but food was not allowed. Animals (rats) were administered aqueous-methanol seed extract orally at dosage levels of 100,250 , and $500 \mathrm{mg} / \mathrm{Kg}$ body weight and kept under examination for $24 \mathrm{~h}$ continuously. The treated animals were observed for the first $2 \mathrm{~h}$ for morbidity and further for mortality for the next $24 \mathrm{~h}$.

If mortality from 2 out of 3 treated animals was observed, the administered dosage was then recognized as a toxic dosage. If mortality was perceived in one animal, the same amount of dosage was repeated again to confirm the toxic dose. If mortality was detected again, the procedure was repeated in lower dosages.

\section{Hepatoprotective property of $C$. intybus}

Six groups of albino Wister rats (Group I, II, III, IV, V, VI) were made comprising six healthy animals of the same weight. The hepatotoxicity was induced by the administration of $\mathrm{CCl}_{4}$ at the dosage level of $0.8 \mathrm{~mL} / \mathrm{Kg}$ according to the induced liver damage-model reported by [18] in all the groups (II-VI) except Group I. Group I was labeled a control that was only provided with a normal diet and was not treated with $\mathrm{CCl}_{4}$, while Group II acted as a negative control. Group III was kept as a positive control and provided with silymarin (standard drug) with the dosage of 25 $\mathrm{mg} / \mathrm{kg}$, while groups IV, $\mathrm{VI}$, and $\mathrm{VI}$ were provided with plant's aqueous-methanol extract. All the doses were given to the animals orally with the help of gastric tubes. Group I rats were given only normal diet for 14 days. Group II animals were given 14 doses of silymarin at 24 hourly intervals. Similarly, 14 doses of test extracts in the concentration range of 100,250 , and 500 $\mathrm{mg} / \mathrm{Kg}$ were given to animal groups III, IV, and V respectively at $24 \mathrm{~h}$ intervals. All the administered doses of the aqueous-methanol extract were given orally to the animals with the aid of gastric tubes. After the 15th day, the samples of blood were collected by piercing the retro-orbital plexus of all animals under mild ethereal anesthesia. Further, liver tissues of the entire treated animal were acquired by scarifying them. The estimation of liver antioxidants as well as histopathological studies were done through the analysis of tissue samples of treated animals. Moreover, the blood samples of treated animals were investigated for their biochemical markers of hepatic injury.

\section{Serum preparation from blood}

The blood of treated animals was taken. The samples were collected in plain sample bottles for biochemical examination, while the whole blood was collected in bottles already having anticoagulant and ethylene diamine tetra-acetic acid (EDTA) for hematogram use [14]. The serum separation was performed by the centrifugation process at the rate of $700 \times \mathrm{g}$ for 20 min. and further examined for biochemical parameters. Before further analysis, the serum was stored at $-80{ }^{\circ} \mathrm{C}$. With the help of an automatic hematology analyzer (Sysmex F-800, Japan) the erythrocytes, leucocytes, and platelets were determined. Furthermore, biochemical parameters such as serum glutamic oxaloacetic transaminase (SGOT), lipid profiles like total cholesterol (TC), alkaline phosphatase (ALP), serum glutamic pyruvic transaminase (SGPT), triglycerides (TG), bilirubin, and creatinine were also estimated by employing the Span Diagnostics Limited kit, Pakistan.

\section{Liver homogenate preparation}

The hepatic tissues of animals were homogenized in a $0.2 \mathrm{M}$ phosphate buffer or 0.2 $M$ tris buffer $(\mathrm{pH} 7.1)$ and centrifuged at $3,000 \times \mathrm{g}$ for $15 \mathrm{~min}$. Liver enzymatic as well as nonenzymatic antioxidants were measured by using a supernatant.

\section{Evaluation of antioxidant enzymes}

A standard protocol was followed to determine the total protein content of the tissues 14]. Enzymatic antioxidants were assayed by determining glutathione peroxidase (GPx) [15], catalase (CAT) [17], and superoxide dismutase (SOD) [18], while the estimation of nonenzymatic anti-oxidants was done through reduced glutathione (GSH) [14] and lipid peroxidation (LPO) [15].

\section{Histopathological studies}

Highly active animals (alive) from each group were selected for histopathological studies. Each selected animal was dissected and liver was removed by the normal process. The removed liver from each animal was preserved in $10 \%$ formalin for $72 \mathrm{~h}$, then the liver was washed with distilled water and then with alcohol and xylene; it was then embedded in paraffin wax. A small section was cut and stained with haematoxylin and eosin for histopathological investigations 
[14]. Liver samples were then sent to UVAS Laboratories Pakistan, for histopathological studies. The liver sections were studied under a fluorescent microscope, and histopathological changes in its structure were observed. Bright and vivid photographs of liver sections were also taken through a fluorescent microscope to support histopathological findings. As a highresolution fluorescence microscope was used for this purpose, photographs clearly showed the changes in hepatocytes due to mortification and inflammation.

\section{Evaluation of antioxidant activities}

\section{DPPH free radical scavenging assay}

Antioxidant evaluation of plant extract was done by 2, 2-diphenyl-1-picrylhydrazyl (DPPH) radical scavenging capacity following the procedure described [19-22].

\section{Ferric thiocyanate (FTC) assay}

Antioxidant activity of the plant extract in terms of the inhibitory effect on linoleic acid peroxidation was assessed by thiocyanate procedure [23-26].

\section{Statistical analysis}

All data obtained from this study was expressed in terms of mean standard deviation and presented as $\pm S D$. ANOVA was applied to estimate the variance between different groups. The significant value was taken as $p<0.045$.

\section{RESULTS}

\section{Acute toxicity}

Results showed that the aqueous-methanol seed extracts of $C$. intybus did not show any mortality until the concentration of $500 \mathrm{mg} / \mathrm{kg}$. When extracts of $C$. intybus were employed in different concentrations $(100,250$, and $500 \mathrm{mg} / \mathrm{kg})$, no impairment was developed in the livers of tested animals; therefore, no mortality was perceived in any experimental group of mice.

\section{Effect of C. intybus seed extract on hematological parameters}

The influence of plant extract at three different dose levels $(100,250$, and $500 \mathrm{mg} / \mathrm{kg}$ ) on hematological parameters is presented in Table 1. The results of hematological parameters indicated that the reduction in the numbers of leucocytes (total WBC count, polymorphs, lymphocytes), erythrocytes (RBC count, hemoglobin, hematocrit, MCV, $\mathrm{MCH}, \mathrm{MCHC}$, RDW), and in platelets was observed in the tested animals due to $\mathrm{CCl}_{4}$ induced hepatic injury. The administration of aqueous-methanol seed extract of $C$. intybus $(100,250$, and 500 $\mathrm{mg} / \mathrm{kg}$ ) led to increased levels of hematological parameters (total WBC count 6950 \pm 0.01 cells $/ \mathrm{cm}^{3}$ RBC count $7.6 \pm 0.04$ milicm $^{3}$ and platelets $430 \pm 0.05$ thou $/ \mathrm{cm}^{3}$ ).

\section{Effect of $C$. intybus seed extract on serum biochemical markers}

Table 2 displays the effect of plant extract (100, $250,500 \mathrm{mg} / \mathrm{kg}$ ) on serum biochemical markers in $\mathrm{CCl}_{4}$ intoxicated rats. The results indicated that hepatic impairment elevated the level of liver enzymes such as ALP (alkaline phosphatase), SGPT (serum glutamic pyruvic transaminase), and SGOT (serum glutamic oxaloacetic transaminase).

Treatment with plant extract at $100 \mathrm{mg} / \mathrm{kg}$ displayed the lesser activity but showed a comparable hepatoprotective activity in terms of decreasing the level of liver enzymes with the treatment at the dosage of $250 \mathrm{mg} / \mathrm{kg}$ in contrast to employed standard silymarin. The maximum hepatoprotective activity counter to decrease the level of liver enzymes was observed with the aqueous-methanol seed extract of $C$. intybus at the dosage of $500 \mathrm{mg} / \mathrm{Kg}$ than standard silymarin (25 mg/kg) as shown in Table 2. The aqueousmethanol seed extract of $C$. intybus decreased the liver markers (biochemical parameters) SGPT (41.21 $\pm 0.94 \mathrm{U} / \mathrm{l})$, SGOT (39.29 \pm 0.18 $\mathrm{U} / \mathrm{I})$, and ALP (109.24 $\pm 0.89 \mathrm{U} / \mathrm{l})$.

Effect of aqueous-methanol seed extract of $C$. intybus on in vivo antioxidant activity

The results of in vivo antioxidant activity exhibited that the level of lipid peroxidation in intoxicated rats increased, while the level of enzymatic antioxidants decreased due to administration of $\mathrm{CCl}_{4}$ at the dosage of 0.8 $\mathrm{mL} / \mathrm{Kg}$ to the Wistar rats (Table 3 ). The aqueousmethanol seed extract of $C$. intybus $(500 \mathrm{mg} / \mathrm{kg}$ ) increased the total protein $(9.95 \mu \mathrm{g} / 10 \mathrm{mg}$ of liver tissue), enzymatic antioxidants SOD (14.2 units $/ \mathrm{min} / \mathrm{mg}$ protein), CAT (48.90 $\mu$ mole of $\mathrm{H}_{2} \mathrm{O}_{2}$ consumed $/ \mathrm{min} / \mathrm{mg}$ protein), GPx (22.1 $\mathrm{mg} \mathrm{GSH}$ consumed $/ \mathrm{min} / \mathrm{mg}$ protein), and GSH (18.1 $\mu$ mole of $\mathrm{GSH} / \mathrm{mg}$ protein). 
Table 1: Effect of aqueous-methanol seed extract of $C$. intybus on hematological parameters in $\mathrm{CCl}_{4}$-induced toxicity in rats

\begin{tabular}{|c|c|c|c|c|c|c|}
\hline Parameter & $\begin{array}{c}\text { Group I } \\
\text { (Control) }\end{array}$ & $\begin{array}{l}\text { Group II } \\
\left(\mathrm{CCl}_{4}\right)\end{array}$ & $\begin{array}{c}\text { Group III } \\
\text { (Silymarin) }\end{array}$ & $\begin{array}{c}\text { Group IV } \\
(100 \mathrm{mg} / \mathrm{kg})\end{array}$ & $\begin{array}{c}\text { Group V } \\
(250 \mathrm{mg} / \mathrm{Kg})\end{array}$ & $\begin{array}{c}\text { Group VI } \\
(500 \mathrm{mg} / \mathrm{Kg})\end{array}$ \\
\hline \multicolumn{7}{|l|}{ Erythrocytes } \\
\hline RBC count $\left(\mathrm{mili} / \mathrm{cm}^{3}\right)$ & $7.1 \pm 0.07$ & $4.1 \pm 0.07$ & $6.7 \pm 0.05$ & $5.4 \pm 0.08$ & $6.9 \pm 0.08$ & $7.6 \pm 0.04$ \\
\hline Hemoglobin (\%) & $13.5 \pm 0.06$ & $7.5 \pm 0.0 .6$ & $12.8 \pm 0.03$ & $9.9 \pm 0.09$ & $11.5 \pm 0.09$ & $13.8 \pm 0.06$ \\
\hline Hematocrit (\%) & $32.3 \pm 0.05$ & $16.9 \pm 0.04$ & $31.3 \pm 0.04$ & $25.9 \pm 0.09$ & $29.8 \pm 0.07$ & $32.9 \pm 0.04$ \\
\hline $\operatorname{MCV}(\mathrm{fl})$ & $47.8 \pm 0.08$ & $55.3 \pm 0.08$ & $45.9 \pm 0.08$ & $53.9 \pm 0.04$ & $50.1 \pm 0.04$ & $47.5 \pm 0.03$ \\
\hline $\mathrm{MCH}(\mathrm{pg})$ & $19.8 \pm 0.09$ & $22.9 \pm 0.05$ & $17.2 \pm 0.04$ & $21.1 \pm 0.04$ & $19.9 \pm 0.03$ & $19.1 \pm 0.01$ \\
\hline $\mathrm{MCHC}(\%)$ & $39.3 \pm 0.08$ & $43.1 \pm 0.08$ & $36.9 \pm 0.01$ & $42.3 \pm 0.06$ & $41.9 \pm 0.09$ & $38.9 \pm 0.07$ \\
\hline RDW (\%) & $12.4 \pm 0.04$ & $14.1 \pm 0.03$ & $10.9 \pm 0.02$ & $13.9 \pm 0.05$ & $12.1 \pm 0.01$ & $12.6 \pm 0.04$ \\
\hline \multicolumn{7}{|l|}{ Leucocytes } \\
\hline Total WBC count & $7300 \pm 0.09$ & $2650 \pm 0.09$ & $5500 \pm 0.07$ & $6000 \pm 0.04$ & $6660 \pm 0.09$ & $6950 \pm 0.01$ \\
\hline$\left(\right.$ cells $\left./ \mathrm{cm}^{3}\right)$ & $8.8 \pm 0.04$ & $10.5 \pm 0.02$ & $9.99 \pm 0.05$ & $10.1 \pm 0.08$ & $9.50 \pm 0.08$ & $9.10 \pm 0.04$ \\
\hline Polymorphs (\%) & $90.1 \pm 0.09$ & $92.9 \pm 0.01$ & $80.9 \pm 0.04$ & $91.9 \pm 0.01$ & $91.1 \pm 0.03$ & $89.8 \pm 0.07$ \\
\hline Lymphocytes (\%) & $536 \pm 0.01$ & $84.9 \pm 0.06$ & $200 \pm 0.06$ & $175 \pm 0.03$ & $250 \pm 0.06$ & $350 \pm 0.05$ \\
\hline Platelets (thou/ $\mathrm{cm}^{3}$ ) & $460 \pm 0.01$ & $94 \pm 0.01$ & $400 \pm 0.03$ & $190 \pm 0.07$ & $250 \pm 0.06$ & $430 \pm 0.05$ \\
\hline
\end{tabular}

Table 2: Effect of aqueous-methanol seed extract of $C$. intybus on biochemical parameters in $\mathrm{CCl}_{4}$-induced toxicity in rats

\begin{tabular}{cccccc}
\hline Group & Treatment & SGOT (U/l) & SGPT (U/l) & ALKP (U/l) & D. Bil (mg/dL) \\
\hline I & Control & $35.9 \pm 0.48$ & $40.8 \pm 0.38$ & $110.9 \pm 0.51$ & $0.61 \pm 0.01$ \\
II & CCl & $58.25 \pm 1.48$ & $56.05 \pm 1.89$ & $139.11 \pm 3.29$ & $0.98 \pm 0.02$ \\
III & Silymarin $(25 \mathrm{mg} / \mathrm{kg})$ & $40.28 \pm 0.19$ & $45.06 \pm 0.14$ & $125.85 \pm 0.35$ & $0.75 \pm 0.01$ \\
IV & C. intybus $(100 \mathrm{mg} / \mathrm{kg})$ & $50.54 \pm 0.62$ & $53.89 \pm 0.98$ & $128.36 \pm 0.39$ & $0.85 \pm 0.08$ \\
V & C. intybus $(250 \mathrm{mg} / \mathrm{kg})$ & $45.67 \pm 0.23$ & $47.44 \pm 0.98$ & $118.41 \pm 0.25$ & $0.79 \pm 0.05$ \\
VI & C. intybus $(500 \mathrm{mg} / \mathrm{kg})$ & $39.29 \pm 0.18$ & $41.21 \pm 0.94$ & $109.24 \pm 0.89$ & $0.68 \pm 0.01$ \\
\hline
\end{tabular}

Data are presented as mean $\pm \operatorname{SEM}(n=6)$

Table 3: Effect of aqueous-methanol seed extract of $C$. intybus on in vivo antioxidant activity in $\mathrm{CCl}_{4}$-intoxicated rats [SOD-superoxide dismutase (units $/ \mathrm{min} / \mathrm{mg}$ protein), CAT-catalase ( $\mu$ mole of $\mathrm{H}_{2} \mathrm{O}_{2}$ consumed $/ \mathrm{min} / \mathrm{mg}$ protein), GPx-glutothione peroxidase ( $\mathrm{mg} \mathrm{GSH}$ consumed/min/mg protein), GSH-reduced glutathione ( $\mu$ mole of $\mathrm{GSH} / \mathrm{mg}$ protein)

\begin{tabular}{ccccccc}
\hline Group & Treatment & Total Protein & SOD & CAT & GPx & GSH \\
\hline I & Control & $10.1 \pm 0.48$ & $15.10 \pm 0.38$ & $50.12 \pm 0.51$ & $21.64 \pm 0.01$ & $18.84 \pm 0.01$ \\
II & CCl $_{4}$ & $5.0 \pm 1.48$ & $7.85 \pm 1.89$ & $30.90 \pm 3.29$ & $12.73 \pm 0.02$ & $11.52 \pm 0.05$ \\
III & Silymarin $(25 \mathrm{mg} / \mathrm{kg})$ & $7.10 \pm 0.19$ & $12.0 \pm 0.14$ & $40.10 \pm 0.35$ & $23.53 \pm 0.01$ & $17.98 \pm 0.09$ \\
IV & C. intybus $(100 \mathrm{mg} / \mathrm{kg})$ & $8.10 \pm 0.62$ & $11.50 \pm 0.98$ & $35.90 \pm 0.39$ & $14.76 \pm 0.08$ & $14.15 \pm 0.06$ \\
V & C. intybus $(250 \mathrm{mg} / \mathrm{kg})$ & $8.89 \pm 0.23$ & $13.0 \pm 0.98$ & $42.90 \pm 0.25$ & $19.26 \pm 0.05$ & $16.20 \pm 0.08$ \\
VI & C. intybus $(500 \mathrm{mg} / \mathrm{kg})$ & $9.95 \pm 0.18$ & $14.20 \pm 0.94$ & $48.90 \pm 0.89$ & $22.10 \pm 0.01$ & $18.10 \pm 0.07$ \\
\hline Data are presented as mean + SEM $(n=6)$ & & & & &
\end{tabular}

\section{Histopathological observations}

The hepatoprotective effect of the plant extract against $\mathrm{CCl}_{4}$ induced hepatic injury confirmed from the result of histopathological investigation. The hepatocytes' impairment, which was produced due to administration of $\mathrm{CCl}_{4}$ in rats, was presented in Figure 1(a). The standard silymarin treated rat liver exhibited portal tract inflammation with lymphocysts and displayed premature fibrosis of the perivenular region (Figure 1d), but the aqueous-methanol seed extracts of $C$. intybus shielded the liver hepatocytes by averting the oxidation in liver cells (Figure $1 b$ and $c$ ). The histopathological studies clearly showed that an increase in the concentration of extract dose (100 to 250 and then $500 \mathrm{mg} / \mathrm{Kg}$ ) prevented the liver damage caused by $\mathrm{CCl}_{4}$.

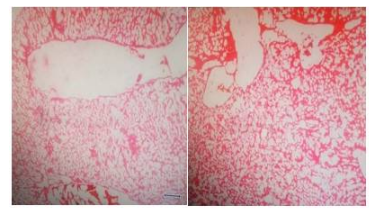

(a)

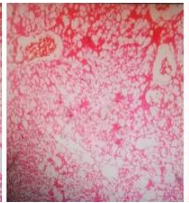

(c)

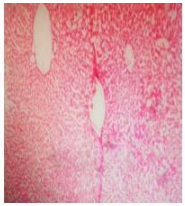

(d)
Figure 1: The Histopathological examination of $\mathrm{CCl}_{4}$ treated and plant extract treated Wistar rats. (a) $\mathrm{CCl}_{4}-$ treated rat liver showing portal tract inflammation with lymphocyst, (b) protective effect of aqueous-methanol seed extract of $C$. intybus $(250 \mathrm{mg} / \mathrm{Kg})$ in the liver of the tested rats, (c) protective effect of aqueousmethanol seed extract of $C$. intybus $(500 \mathrm{mg} / \mathrm{Kg})$ in the 
liver of the tested rats, (d) $\mathrm{CC}_{4}$-treated rat liver showing early fibrosis of the perivenular region

\section{Antioxidant activities}

\section{DPPH free radical scavenging activity}

DPPH radical scavenging for different concentrations of aqueous-methanol seed extracts of $C$. intybus are presented in Figure 2. The maximum DPPH radical scavenging in terms of $I_{50}$ value $(80 \pm 0.22 \mu \mathrm{g} / \mathrm{mL})$ was perceived with the concentration of $60 \mu \mathrm{g} / \mathrm{mL}$, whereas the lowest $\mathrm{IC}_{50}$ value $(41 \pm 0.33 \mu \mathrm{g} / \mathrm{mL})$ was achieved with the concentration of $1000 \mu \mathrm{g} / \mathrm{mL}$ (Figure 2). The other concentrations $(125,250$, and $500 \mu \mathrm{g} / \mathrm{mL}$ ) of plant extract demonstrated the $\mathrm{IC}_{50}$ values $74 \pm 0.53,66 \pm 0.64,51 \pm 0.12 \mu \mathrm{g} / \mathrm{mL}$ respectively in scavenging the DPPH free radical. DPPH radical scavenging increased with increasing concentration of aqueous-methanol plant extract. At all levels of concentrations from $60 \mu \mathrm{g} / \mathrm{mL}$ to $1000 \mu \mathrm{g} / \mathrm{mL}$, the aqueous-methanol seed extract of $C$. intybus manifested the noteworthy and significant DPPH radical scavenging propensity, which was analogous to standard $\mathrm{BHT}\left(\mathrm{IC}_{50}=84 \pm 0.54 \mu \mathrm{g} / \mathrm{mL}, 76 \pm 0.81\right.$ $\mu \mathrm{g} / \mathrm{mL}, 65 \pm 0.49 \mu \mathrm{g} / \mathrm{mL}, 55 \pm 0.39 \mu \mathrm{g} / \mathrm{mL}, 43 \pm 0.51$ $\mu \mathrm{g} / \mathrm{mL}$ ) with the same concentration level of plant extract. This demonstrates that the aqueousmethanol seed extract of $C$. intybus holds extraordinary antioxidant potential in terms of scavenging the DPPH free radicals.

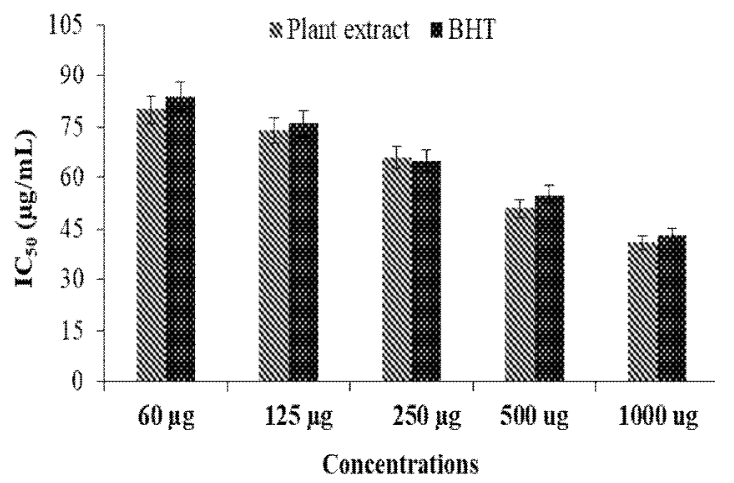

Figure 2: DPPH radical scavenging activity of the seed extract of $C$. intybus

\section{Antioxidant activity via inhibition of linoleic acid oxidation}

The antioxidant propensity at different concentrations of plant extract was estimated by means of the percentage inhibition of linoleic acid peroxidation (Figure 3). The \% inhibition of linoleic acid peroxidation was $33 \pm 0.11,45 \pm 0.28$, $57 \pm 0.35,65 \pm 0.37$, and $73 \pm 0.42$ at different concentrations of $60,125,250,500$, and 1000 $\mu \mathrm{g} / \mathrm{mL}$ of plant extract, respectively. The highest inhibition of linoleic acid peroxidation was $73 \pm 0.42 \%$ (for $1000 \mu \mathrm{g} / \mathrm{mL}$ of aqueous-methanol seed extract of $C$. intybus), while the lowest percentage inhibition $(33 \pm 0.11 \%)$ was recorded for $60 \mu \mathrm{g} / \mathrm{mL}$ concentration of plant extract. The linoleic acid peroxidation was significantly inhibited by the aqueous-methanol seed extract of $C$. intybus at all the levels tested, and all the results for the percentage inhibition of linoleic acid were superior than that of standard BHT, which showed $30 \pm 0.27,41 \pm 0.38 \%, 53 \pm 0.45 \%$, $60 \pm 0.29 \%$, and $69 \pm 0.11 \%$ inhibition for its different concentrations $(60,125,250,500$ and $1000 \mu \mathrm{g} / \mathrm{mL}$ ) respectively (Figure 3 ).

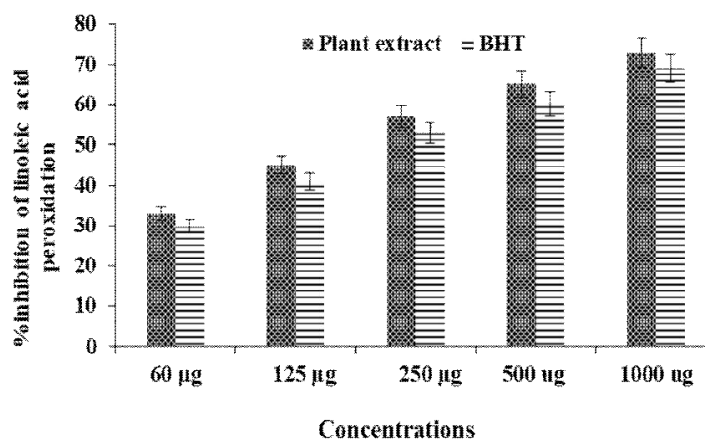

Figure 3: Antioxidant activity of seed extract of $C$. intybus by inhibition of linoleic acid peroxidation

\section{DISCUSSION}

Poisonous chemicals, toxic as well as non-toxic drugs, and viral penetrations can severely damage the liver, causing heptocellular diseases [1]. Fatty liver, necrosis, and cirrhosis are the most significant pathological features of $\mathrm{CCl}_{4}$ that induce hepatotoxicity [7]. A free radical species which is responsible for this hepatotoxicity is formed by the free radical mechanism of $\mathrm{CCl}_{4}$ [8]. This species is ${ }^{\circ} \mathrm{CCl}_{3}$, which is first produced and then catalyzed by the action of an enzyme named as cytochrome p450. This enzyme is usually used to transform or catalyze the poisonous drugs, compounds or chemicals in the interconnected network of tubular membranes [9]. Hepatotoxicity induced by $\mathrm{CCl}_{4}$ in normal rats increased the levels of biochemical framework prominently [10]. The animals treated with aqueous alcoholic extract of $C$. intybus exhibited a remarkable decrease in all the serum parameters intoxicated by $\mathrm{CCl}_{4}$. Silymarin also exhibited the same results as test extracts. Flavonoids and phenolic compounds are responsible for the antioxidant and hepatoprotective activities of plants [14]. These natural products found in plant and seed extracts could be responsible for the hepatoprotective effects [10]. 
Therefore, from the present study it is concluded that aqueous-methanol extracts exhibited remarkable antioxidant and hepatoprotective activity. It can also be proposed that alcohol soluble compounds may also be present in the seeds of $C$. intybus Linn, which behave as an active ingredient. These alcohol soluble compounds are poly-phenolics or flavonoids, which may protect the liver against the damage caused by free radicals. Future research work is needed to evaluate practical usefulness of $C$. intybus by separating and isolating natural polyphenolics or flavonoids through different techniques.

The different concentrations of aqueousmethanol seed extract of $C$. intybus were also examined for their antioxidant propensity by total antioxidant assays (inhibition of linoleic acid peroxidation and DPPH radical scavenging). All the concentrations of aqueous-methanol seed extract of $C$. intybus exhibited the comparable antioxidant activity results with standard BHT. However, in case of inhibition of linoleic acid peroxidation, all the concentrations of aqueousmethanol seed extract of $C$. intybus manifested the significant and improved antioxidant results in comparison with the standard BHT. Moreover, the results for plant extracts at different concentrations also indicate that the antioxidant activity of the aqueous-methanol seed extract of C. intybus was concentration-dependent [9].

The plant extract showed enhanced antioxidant properties with increase in concentration. The presence of flavonoids and phenolics in seeds of C. intybus has been previously reported [27]. Potent antioxidant activities of $C$. intybus seeds have been reported previously in literature, where $100 \%$ methanolic extract showed the highest antioxidant potential [27]. The results showed that plant $C$. intybus is a rich source of natural antioxidants based on flavonoids and polyphenolics [10]. The antioxidant results of $C$. intybus in current research study are in close agreement with the previously reported studies [8].

\section{CONCLUSION}

The findings of this study research demonstrate that the aqueous-methanol seed extract of $C$. intybus has potent antioxidant and hepatoprotective activities. This may be due to the presence of flavonoids or poly-phenolic compounds, which are known to exhibit hepatoprotective and antioxidant properties. Consequently, the seed extract of $C$. intybus (Linn.) has some potentials for use in pharmaceutical, nutraceutical, and cosmetic industries.

\section{DECLARATIONS}

\section{Acknowledgement}

This work was supported by the Department of Chemistry, School of Science, University of Management and Technology, Lahore, Pakistan. The authors are also grateful to Dr Ahmad Adnan (Department of Chemistry, GC University Lahore, Pakistan) for access to the animal facility for the animal studies; to the plant taxonomist, Prof. Sohail Sheikh (Department of Botany, Govt M.A.O. College, Lahore, Pakistan) for suggestions and authentication of the plant materialused; and also to the University of Veterinary and Animal Sciences, Lahore, Pakistan for histopathological studies.

\section{Conflict of interest}

No conflict of interest is associated with this study.

\section{Contribution of authors}

We declare that this work was done by the authors named in this article and all liabilities pertaining to claims relating to the content of this article will be borne by the authors. All authors equally contributed to this work.

\section{REFERENCES}

1. Khan SA, Rasool N, Riaz M, Nadeem R, Rashid U, Rizwan K, Zubair M, Bukhari IH, Gulzar T. Evaluation of Antioxidant and Cytotoxicity Studies of Clerodendrum inerme. Asian J Chem 2013; 13: 7457-7462.

2. Khan $S A$, Shahid $S$, Jameel $M$, Ahmad $A$. In vitro antibacterial, antifungal and GC-MS analysis of seeds of Mustard Brown. Int J Pharm Chem 2016; 6(4): 107-115.

3. Khan SA, Shahid S, Khan ZA, lqbal A. Assessment of stabilization of canola oil, free radical scavenging and cytotoxic potential of Peucedanum graveolens (roots). Int J Sci Res Pub 2016; 6(3): 529-535.

4. Khan SA, Shahid S, Ahmad W, Ullah S. Pharmacological Importance of Clerodendrum Genus: A Current Review. Int J Pharm Sci Res 2017; 2(2): 22-30.

5. Khan SA, Jameel M, Kanwal S, Shahid S. Medicinal Importance of Allium Species: A current review. Int $J$ Pharm Sci Res 2017; 2(3): 29-39.

6. Khan SA, Shahid S, Sajid MR, Noreen F, Kanwal S. Biogenic Synthesis of CuO Nanoparticles and their Biomedical Applications: A Current Review. Int $J$ of Adv Res 2017; 5(6): 925-946. 
7. Zafar R, Ali SM. Anti-hepatotoxic effects of roots and root callus extracts of Cichorium intybus $L . J$ Ethnopharmacol 1998; 63: 227-231.

8. Kim M, Shin HK. The Water-Soluble Extract of Chicory Reduces Glucose uptake from the Perfused Jejunum in Rats. J Nutr 1996; 126(9):2236-2242.

9. Gilani AH, Molla N, Atta urRehman, Shah $B H$. Phytotherapy the role of natural products in modern medicine. J Pharma Med 1992; 2: 111-118.

10. Heckendorn F, Häring DA, Maurer V, Senn M, Hertzberg $H$. Individual administration of three tanniferous forage plants to lambs artificially infected with Haemonchuscontortus and Cooperiacurticei. Vet Parasitol 2007; 146(1-2): 123-34.

11. Khan SA, Shahid S, ljaz F. Green Synthesis of Copper oxide Nanoparticles \& Biomedical Application. Publisher: Lambert Academic Publishing ISBN: 978620-2-02718-2 1, 2017; 1-133.

12. Ijaz F, Shahid S, Khan SA, Ahmad W, Zaman S. Green synthesis of copper oxide nanoparticles using Abutilon indicum leaf extract: Antimicrobial, antioxidant and photocatalytic dye degradation activities. Trop J Pharm Res 2017; 16(4): 743-753.

13. Ahmad W, Khan SA, Munawar KS, Khalid A, Kanwal S. Synthesis, characterization and pharmacological evaluation of mixed ligand-metal complexes containing omeprazole and 8-hydroxyquinoline. Trop J Pharm Res 2017; 16(5): 1137-1146.

14. Jeyasekar P, Mohanan PV, Rathinak K. Hepatoprotective activity of ethyl acetate extract of Acacia catechu. Indian J Pharmacol 1997; 29: 426-428.

15. Khan SA, Ahmad W, Munawar KS, Kanwal S. Synthesis, Spectroscopic Characterization and Biological Evaluation of $\mathrm{Ni}(\mathrm{II}), \mathrm{Cu}(\mathrm{II})$ and $\mathrm{Zn}$ (II) Complexes of Diphenyldithiocarbamate. Indian J Pharm Sci 2018; 80(3): 480-488.

16. National Institutes of Health Office of Laboratory Animal Welfare. Public Health Service policy on the humane care and use of laboratory animals. Bethesda, MD: NIH. 2002. Retrieved September 27, 2011.

17. Khan SA, Shahid S, Jabin S, Zaman S, Sarwar MN, Synthesis and characterization of un-doped and copperdoped Zinc Oxide nanoparticles for their optical and antibacterial studies. Dig J Nanomater Biostruct 2018; 13(1): 285-297.
18. Mally HT, Evelyn KA. Estimation of serum bilirubin level. J Biol Chem 1937; 119: 481.

19. Khan $S A$, Noreen $F$, Kanwal S, lqbal A, Hussain G. Green synthesis of $\mathrm{ZnO}$ and Cu-doped $\mathrm{ZnO}$ nanoparticles from leaf extracts of Abutilon indicum, Clerodendrum infortunatum, Clerodendrum inerme and investigation of their biological and photocatalytic activities. Mater Sci Eng C 2017; 82(C): 46-59.

20. Khan SA, Shahid S, Bashir W, Kanwal S, lqbal A. Synthesis, characterization and evaluation of biological activities of manganese-doped zinc oxide nanoparticles. Trop J Pharm Res 2017; 16(10): 2331-2339.

21. Khan SA, Shahid S, Kanwal S, Hussain G. Synthesis characterization and antibacterial activity of $\mathrm{Cr}$ (III), Co (III), Fe (II), Cu (II), Ni (III) complexes of 4-(2-(((2hydroxy-5-nitrophenyl) diazenyl) (phenyl) methylene) hydrazinyl) benzene sulfonic acid based formazan dyes and their applications on leather. Dyes Pigm 2017; 148(C): 31-43.

22. Khan SA, Noreen F, Kanwal S, Hussain G. Comparative synthesis, characterization of Cu-doped $\mathrm{ZnO}$ nanoparticles and their antioxidant, antibacterial, antifungal and photocatalytic dye degradation activities. Dig J Nanomater Biostruct 2017; 12(3): 877-889.

23. Qamar MA, Shahid S, Khan SA, Zaman S, Sarwar MN. Synthesis Characterization, Optical and Antibacterial Studies of Co-doped SnO2 Nanoparticles. Dig J Nanomater Biostruct 2017; 12(4): 1127-1135.

24. Khan SA, Kanwal S, lqbal A, Ahmad W. Cu and Mn complexes of Nicotinic acid and Imidazole: a current review. Int J Advanc Res 2017; 5(4): 1350-1368.

25. Hussain G, Khan SA, Ahmad W, Athar M., Saleem R. A kinetic study of rubazoic acid formation derived from 4Amino-1(4Sulphophenyl) 3-Methyl-2-Pyrazolin-5-One. Int J Advanc Res 2017; 5(4): 234-241.

26. Shahid S, Khan SA, Ahmad W, Fatima U, Kanwal S. Size-dependent Bacterial Growth Inhibition and Antibacterial Activity of Ag-doped ZnO Nanoparticles under Different Atmospheric Conditions. Indian J Pharm Sci 2018; 80(1): 173-180.

27. Mehmood N, Zubair M, Rizwan K, Rasool N, Shahid M, Ahmad V. Antioxidant, Antimicrobial and Phytochemical Analysis of Cichorium intybus Seeds Extract and Various Organic Fractions. Iran J Pharm Res 2012; 11(4): 1145-1151. 